[Meade, A., \& Dalli, C. (1992). Review of the Early Childhood Sector. New Zealand Annual Review of Education, 1, 113-132]

\section{Review of the Early Childhood Sector}

\section{ANNE MEADE AND CARMEN DALLI}

$\mathrm{T}$

he year 1991 continued to be a time of change for those in the early childhood sector. This was no surprise, because 1990 had ended with two significant announcements. The first was that the Minister of Education had promulgated revised guidelines for the recently introduced charters. The second announcement was that all educational services were again to be subjected to a series of reviews four of which would be in the early childhood sector. These announcements followed hard on the heels of the promulgation in September 1990 of the Education (Early Childhood Centres) Regulations 1990. Changes in early childhood qualifications and training were also being implemented and teething problems were becoming evident. Meanwhile, debate about the proposed introduction of the "Parents as First Teachers" (PAFT) project continued. Overall, at the end of 1990, the early childhood education sector was still undergoing great change and was described as in need of some stability and consolidation (e.g., Dalli, 1990a).

Stability and consolidation were indeed what most early childhood organisations and their users had been hoping for in 1991. However, the general desire that 1991 would give the early childhood sector time to concentrate on growth and development of quality had to be quickly pushed aside (Wells, 1991)

The first half of 1991 was spent writing submissions to the review teams dealing with early childhood issues, digesting the new regulations and waiting nervously for the Budget. Anxiety mounted when the first convenor of the funding review team resigned (presumably in protest) and an independent member, Crispin Gardiner,

\section{Anne Meade and Carmen Dalli}

filed a minority report (Dominion, May 3 1991). Subsequently, officials' activity on early childhood funding shifted from the Ministry of Education to the States Services Commission.

The Budget announcements included first-phase realisation of the "Parents as First Teachers" policy and news that many had feared about reductions in funding (\$18 million less for under 2 year olds) and in quality requirements for charters. As well, bulk funding of kindergarten teachers' salaries was announced. A complete surprise was the reduction of funding for advisory support and in-service training, and the tendering out of a sizeable proportion of the work of the Early Childhood Development Unit.

In this paper, we propose to comment on the revised guidelines for charters for early childhood services (the Statement of Desirable Objectives and Practices), and on some aspects of the reviews and the Budget announcements made following those reviews. We particularly consider early childhood qualifications and training developments, and comment on the new policy "Parents as First Teachers" (PAFT).

\section{Historical Background}

A brief historical comment about early childhood services in Aotearoa/New Zealand may be helpful as a background. Kindergartens and childcare centres have existed for over 100 years, and playcentres celebrated their 50th anniversary in 1991. 1992 will be the tenth anniversary of Te Kohanga Reo. The sector is characterised by choice and diversity, and it is widely acknowledged that this diversity provides strength. Services may be home-based or centre-based. Most are owned and managed by community-based, non-profit voluntary associations or trusts, with a small proportion being run by private organisations. Delivery patterns are very diverse. Training is also diverse in terms of approach, focus, length and providers. The task for policy-makers always is to be clear about intended results, to be even-handed and, at the same time, to allow some variation to maintain the diversity. 


\section{The Quality Debate, the New 1990 Regulations and Charters}

The issue of ensuring quality early childhood services for Aotearoa/New Zealand has been at the forefront of early childhood educational debate for a number of years (e.g., Smith \& Swain, 1988; Meade, 1988; Farquhar, 1990; see also Dalli, 1990b). Ensuring a quality service was a specific aim of the Before Five reforms. In 1991, the debate was often couched in terms of quality assurance and quality practice, a useful distinction made by Irene Balaquer and Helen Penn (1990). Quality assurance is mostly the responsibility of government policy makers. Quality practice, on the other hand, is mostly the responsibility of early childhood staff and parents in local centres and home-based schemes.

Generally, quality assurance is created through the mechanisms of regulations, advisers and monitors, and the provision of training (preservice and in-service) for early childhood teachers. In Aotearoa/New Zealand, we have all these and more. Regulations pertaining to all services have been promulgated, the Early Childhood Development Unit provides advisory support and in-service training, Colleges of Education now offer Diploma of Teaching courses for early childhood teachers and the Education Review Office monitors performance. Other organisations also offer a variety of training courses.

What we saw with the introduction of the 1990 Regulations was government attention being given to quality features which could be handled by the state and which research has shown to benefit children (e.g., Smith \& Swain, 1988; Kagan, 1990). The Regulations were encouraging for early educators and reassuring for parents. They showed that the state was concerned for its youngest citizens. Although some centres had trouble finding resources to meet minimum standards in time, especially when Cabinet imposed a moratorium on discretionary grants through Term 1, 1991, and although some found one or two requirements to be excessive, few disagreed with the idea of standards to provide assurance.

In addition to the Regulations' standards, Aotearoa/New Zealand has another mechanism for quality assurance: charters ${ }^{1}$ Since 1990 , to qualify for chartering and concomitant higher funding, centres have had to meet additional quality guidelines published in the Management
Handbook (1989) and supplemented by the Ministry of Education in November 1990 through the document Conditions for Receipt of the Early Childhood Bulk Grant.

Clearly, therefore, the path to quality assurance was being firmly trodden.

There was, however, one area that neither the 1990 Regulations nor the mid-November conditions dealt with appropriately. In neither was there any cognisance of the different blueprints needed for the success of early childhood services for children from different cultural backgrounds. At the Fifth Early Childhood Convention, in September 1991, one of us (Meade, 1991a) highlighted an observation by Urie Bronfenbrenner (1979). Bronfenbrenner said:

Within any culture or subculture, settings of a given kind tend to be very much alike, whereas between cultures they are distinctly different. It is as if with each ... culture and subculture there existed a blueprint for the organisation of every kind of setting. Furthermore, the blueprint can be changed, ... and produce corresponding changes in behaviour and development (1979, p. 4).

Anne Meade used this hypothesis to talk about a different blueprint for Maori. She said:

those who attended the hui in 1980 and shaped the vision for Te Kohanga Reo decided that in order to change the achievement patterns for Maori children, a move away from the "blueprint" for mainstream early childhood settings was required. A Maori blueprint was established. The ensuing positive changes in behaviour and development of Maori children attending nga kohanga reo are now well known (McNaughton \& Ka'ai, 1990).

While the government was taking note of the fact that different blueprints apply where early childhood education occurs in homes versus in centres, and is developing a Code of Practice for home-based schemes, there was, and still is, no recognition of a different blueprint for Te Kohanga Reo in the Regulations; they too need a code of practice. Obviously, this needs to be devised by Maori. And, by corollary, Pacific Island language groups also would benefit from their own codes. The 
Education Amendment Act (1990) does not limit the number of codes of practice.

In our view, without some diversity in providing for quality assurance that is in accord with different cultural blueprints, the state is in danger of inhibiting the development of kohanga reo and language groups and, more importantly, the development of the children and adults in them.

\section{Revised Guidelines for Charters: The Statement of Desirable Objectives \\ and Practices}

We noted above that the quality conditions required for chartering were soon superseded. Indeed this happened barely a month after the midNovember quality conditions reached centres. On 14 December 1990, a supplement to the Education Gazette carried "A Statement of Desirable Objectives and Practices", or DOPs as it is colloquially referred to, promulgated by the Minister on 6 December 1990. The introduction to the statement says:

Early childhood centres should note that their charter status depends on their continuing to meet all the requirements for a licence as set out in the Education (Early Childhood Centres) Regulations 1990 (Education Gazette Supplement, 14 Dec, 1990, p. 1).

The effect of this statement was to immediately revoke much of the power of the quality guidelines to require higher standards than those in the 1990 Regulations for chartering purposes.

In her keynote address to the Fifth Early Childhood Convention held in September 1991, Meade (1991a) has already criticised the devaluing of the charter by the DOPs. She notes that the law permits (but does not require) the Minister of Education to gazette a statement of desirable objectives and practices. This option was adopted. The introduction claims that the DOPs are based closely on the Early Childhood Management Handbook. A close look at the Statement, however, reveals a number of important differences:

1. There is an increase of central control over the content of the charters. The Early Childhood Management Handbook had a mix of requirements and objectives that management had to plan towards. Now, there are over 60 required objectives and practices listed in the Statement. They are deemed part of all charters. Note the prescriptive language:

These objectives and practices are deemed to be part of the charter of every chartered early childhood centre ... and are to apply to the management and staff of every chartered early childhood service. [authors' emphasis]

The way in which these objectives and practices are to be met, together with any other objectives and practices particular to an early childhood service which do not run counter to the objectives and practices as set out in this statement, shall be set out in the charters of each early childhood service (ibid, p. 1.).

The guidelines in the Management Handbook (1989) emphasised developmental principles and strategies; the word "plan", indicating a developmental approach, was extensively used in the handbook but is far less evident in the DOPs. As well, the parts that centres can plan for themselves, and therefore "own" are now buried.

2. It is clear that the requirements themselves have, in fact, changed. For instance the section regarding the Treaty of Waitangi has gone; this is despite the claim that "The(se) modifications are minimal and do not alter the substance of the original requirements" (ibid).

3. Although the Te Kohanga Reo Trust has negotiated its own charter guidelines, the Gazette Statement does not make it clear whether or not Te Kohanga Reo are exempt from these new charter guidelines; indeed it is silent about the fact that the Te Kohanga Reo guidelines exist. There are many references in the Statement to its application to every chartered early childhood centre.

The question arises: given that each Ministry of Education district has reasonable autonomy about chartering procedures, does the use of the Trust guidelines vary from district to district? Are some Ministry liaison officers taking the Statement into kohanga reo instead of the Trust charter guidelines? 
A further strong criticism of the DOPs is that it has undermined the value of the process of writing charters. This process was intended to be, and often has been, the enormous strength of charters (Farquhar, 1991). Many people's reactions changed in 1991: charters became a bureaucratic nuisance rather than a constructive tool for growth and development (e.g., Meade, 1991a; Varnham, 1991).

Clearly, therefore, the way the Statement of Desirable Objectives and Practices has been introduced has undermined local "ownership". We have heard examples where Ministry liaison officers have gone in with a Statement and said to centre staff, "Don't worry about your charter, just sign that you will do what it says."

The "sign here" approach has three negative effects. First, research (Meade, 1985; Smith \& Swain, 1988) shows that staff goals strongly influence child outcomes. The adults associated with the service will not "own" the Statement's objectives unless given the chance to work through them. Moreover, they may stop reflecting on goals and objectives, because there are now over 60 objectives given to them by the government. Who would want to create more of their own?

Second, it is staff who are being approached to sign the Statement, thus driving a wedge between staff, and parents and managers. The charter development process was significant in the lives of centres in 1990, in building closer relationships between staff, parents and management. Where parents and staff have worked together, outcomes are more significant for children and other family members (e.g., Athey, 1990). The "sign here" exponents discount (even nullify) the significance of that collaborative work.

Third, if handling of the Statement has come to the point of officials saying "Don't worry about your charter...", the Statement has become a juggernaut rather than guidelines. It could kill charters and the valuable processes associated with them. In our view, that would not be in the best interests of children or society.

\section{Four Reviews in the Early Childhood Sector}

In December 1990, the Government announced 17 reviews in education as part of its preparation for the Budget 1991 - four of them focussing on early childhood care and education. It seemed extraordinary that around $25 \%$ of the reviews were on a sector which takes about $4 \%$ of Vote: Education and very small proportions of Votes: Social Welfare and Maori affairs. The reviews covered property aspects of the Education (Early Childhood Centres) Regulations 1990, funding, staffing and training and qualifications, and the Early Childhood Development Unit.

\section{Property}

The updating of the property clauses in the 1990 Regulations had led to concerns being expressed about establishment costs for new centres. Prior to the Budget it was announced that some minor changes would be made to the regulations to ease the financial costs to those establishing centres or renovating premises. When the review on property was announced a moratorium on grants for establishing and upgrading centres was also imposed. As a result some centres either faced the increased cost themselves, or failed to meet the deadline for up-grading to charter standards. This short term result left some centres bemused but in the long term, the changes seem sensible.

\section{Funding}

The funding discussions were apparently heated and difficult, going by the fact that the convenor of the first review team resigned before reporting, and an independent member of the first team forwarded a minority report to the Prime Minister. The replacement team therefore had less time to complete their report in the run-up to the Budget.

Four options were put by the Funding Review Team to the Prime Ministerial Committee on the Reform of Social Assistance in May 1991:

\section{Status Quo}

This "represents the current funding model with expenditure capped at the 1990/91 level."

\section{Mixed, Targeted and Universal Funding}

The status quo was to be varied by: a) lowering the under twos' rate to $\$ 4$ per hour per child (from \$7.25), and lowering the kindergarten rate 
to $\$ 2.25$ from ( $\$ 2.70)$ to match other services. The "savings" were to be transferred to the Department of Social Welfare (DSW) fees subsidy (operated on an income targeting basis).

\section{Pure Targeting: Change Team Regime}

No funding would go to regular service providers. All previous funds would go to eligible families (mainly low income) using an abatement system for middle income families. Developmental funding to new services would be increased.

4. Pure Targeting: Interim Targeting Regime

Again, no funding would go to regular providers of early childhood services. Early Childhood subsidies to families would "piggy back" on to the health user charges system of targeting; that is, families would be divided into low, medium and high-income groups and attract different subsidies according to their category.

[Funding Review Team Report, 1991]

The Budget revealed that Cabinet decided to change the funding, but it did not adopt either of the two most radical options. The Government announced that it would be lowering the under twos' rate to $\$ 4.50$ (not to $\$ 4$ as recommended) and all other rates would remain as they were, capped (that is, kindergartens were not cut). The \$18 million which would be "saved" from the universal funding ${ }^{2}$ was to be transferred to targeted families.

Another early childhood funding working group was established the third in 1991. It was to focus on targeting options. In a quiet announcement in the spring, Hons J. Luxton and J. Shipley revealed that the targeting involved an upgrading of the existing DSW fees subsidy for low income families and the existing establishment grants scheme. The scope of the DSW fees subsidies was extended to improve accessibility; and the Pacific Island language groups, who were struggling to attain charter status, were targeted to receive some extra discretionary grants. In total, these targeting changes would cost "up to $\$ 16$ million" and therefore did not equal the earlier cut of $\$ 18$ million. It would appear that the balance has gone to "Parents as First Teachers." The first allocation of targeted discretionary grants was made by the end of 1991 due to a collaborative effort by the Ministry of Education and the Early Childhood Development Unit.

The full impact of the decisions to shift funding from universal to targeted recipients is yet to be revealed since they are to be implemented in 1992. By the end of 1991 it was known at an anecdotal level that the number of under-twos places will reduce, parent fees are likely to be over $\$ 150$ per infant per week in city centres and ratios are more likely to be the minimum allowed of 1:5 even though the literature (e.g., Bredekamp, 1987) is clear that a 1:3 ratio is needed for infants up to 18 months of age. The most marked impact is on centres, because their incomes drop and quality does too. The fees subsidy does not make up the difference.

Families under stress, who used to receive a full fees subsidy, now have to fit an income-based sliding scale. Although the last change was to be phased in, groups for children with special needs are predicting affordability problems fairly immediately.

Many concerns have arisen from this; the cut in bulk funding for infants and toddlers seems suspiciously to have been designed to keep women at home (see also Lauder, 1991), either because they cannot afford early childhood care and education fees, or because they cannot find the quality care they know very young children need. A further worry is that any reduction in quality is likely to impact on staff as well as children; for example, a worsened ratio is known to be associated with staff burnout and the consequential turn-over has adverse effects on young children (Whitebook et al., 1989).

A further funding decision was that kindergarten salaries would be bulk-funded. This decision has not been welcomed by the Combined Early Childhood Union of Aotearoa (CECUA) and has already had an unintended consequence. Four of the larger associations have seceded from the national organisation (the NZ Free Kindergarten Union). It appears that they disagreed over the issues and procedures for handling salaries bulk funding. The details of the kindergarten bulk funding formula had not been finalised at the time of writing. The major 
concerns were: a) how to deal with the uneven distribution of threeteacher kindergartens versus two-teacher kindergartens (because the staged increase in third teachers was halted soon after the National Government was elected in 1990); and b) how to fund and employ senior teachers who currently may work across Association boundaries.

\section{Staffing, Training and Qualifications}

The Budget held four announcements that related to staffing and training and qualifications - none of which inspired early childhood educationists with much enthusiasm. Firstly, the total number of points required for early childhood staff to be deemed fully qualified was reduced. Secondly, funds for in-service training and advisory support were reduced. Thirdly, registration of kindergarten teachers ceased to be compulsory. The fourth announcement was the change in the minimal staff/child ratio for under two year olds in mixed age group centres from $1: 4$ to $1: 5$. The impact of each of these changes is considered next.

\section{a) Reduction of points for full qualification}

The clear message of this decision to women (who almost exclusively staff early childhood centres) was that there was little to be gained by upgrading their qualifications. For years, those in early childhood care and education in Aotearoa/New Zealand have aspired to the benchmark of three year training to help realise the goal of a quality service as well as to enhance the professional status of early childhood staff. In 1988, three year training became a reality. In August 1990, the Government released a modest document called Early Childhood Qualifications and Training: A Blueprint for the Future. In the tradition of early childhood education in this country, diversity was affirmed. Individuals or groups could attain the benchmark in diverse ways, depending on their background. This document started everyone in the early childhood sector discussing "points": three year training or its equivalent was given 120 points, two year training or its equivalent was given 80 points, and one year was the same as 40 points.

When the New Zealand Qualifications Authority was established in mid-1990, it had to grapple with the fact that a large proportion of early childhood teachers had not only a 40- or 80-point qualification, but they also had prior experience which should be recognised. As an interim step, they agreed that people who had an acceptable combination of specified qualifications and experience should all be awarded 100 points towards a Diploma of Teaching (ECE) equivalent.

This arrangement was only an interim measure to assist alreadytrained people in up-grading to a 120-point qualification. As it happened, it also helped the sector by indicating which people had enough points to qualify for licences, because licensing calls for a person-in-charge to have 80 points (now 100 points by 1995) and many such persons would have had fewer if their prior experience was not recognised.

This "grand-parenting" was only an administrative convenience. 100 points has never been, and still is not, a qualification. The procedure was to have been phased out in another few years when staff had upgraded to a 120-point qualification, which was to be the level required of supervisors and head teachers by 1 January 1995.

However, the 100 points notion will stay alive a while longer. Budget announcements included a decision to set 100 points as the benchmark needed for licences from 1 January 1995. This is what we would describe as a "neither fish nor fowl" decision. The Review Team considering staffing matters recommended staying with the 120 point benchmark for licensing; the State Services Commission recommendation was for 80 points. Cabinet went for a compromise, and decided on 100 points by 1995 . After a degree of lobbying, particularly by CECUA and during the Fifth Early Childhood Convention, a subsequent decision was to set the year 2000 as the deadline for the 120point benchmark.

Qualifications, and points required for licences and charters are two different things. There is no 100-point qualification. No diploma or certificate goes to those "grand-parented" to 100 points. If individuals want a qualification, then they have diverse avenues for obtaining certificates or diplomas. Incentives for obtaining certificates have diminished because of the Budget announcements and because of some unfortunate fumbling in the implementation of recognising upgraded 
courses by the New Zealand Qualifications Authority. However, the attainment of a credible qualification has not been lost - only postponed.

The next challenge will be to translate the certificates and diplomas into units of learning which fit into the Qualifications Framework announced by the Government and New Zealand Qualifications Authority in November 1991, and, at the same time, to advance the thinking and procedures for recognising prior learning beyond what had already been trialled by the early childhood sector in 1990/91 (Meade \& Kennedy, 1992). With the Te Kohanga Reo Kaiako Certificate course about to start in 1992, adoption of "units of learning" could well be yet another threat to the diversity in the early childhood sector and to the different "blueprints" for early childhood care and education for Maori and for Pacific Island communities.

(b) Reduction in Funds for In-service Training and Advisory Support from the Early Childhood Development Unit

One Budget decision no-one in the field predicted was making contestable, by tendering out, a major aspect of the Unit's work. The announcement read:

ECDU's present programmes of advisory support for licensed or chartered early childhood services, and in-service training and management development, will be made available to any organisation that can undertake this work. \$2.698 million will be made available to fund these two programmes. $\$ 1.047$ million will be saved in the 1991/92 financial year and a further $\$ 1.3$ million in 1992/93 (Smith, 1991, p. 40).

This constituted a massive cut to the Unit's operating budget. Taken together with the fact that funding for advisory support and in-service training for early childhood centre staff, managers and parents was severely reduced, this announcement strengthened the message to women that upgrading qualifications was not valued. It also rendered more suspect the Government's commitment to a quality early childhood education. The Ministry of Education called for tenders for these programmes the day after the Budget. In response, the ECDU
Board eventually took legal action because of an alleged breach of contract by the Ministry of Education. Five months later, an out-of-court agreement was obtained which indicated that such an abrupt shift to a contestable regime was indeed a breach of contract.

This decision if ever implemented would be divisive, not only within the Unit, but of the whole early childhood sector. Unity of interests in the sector has had very positive consequences in recent years. Now moves such as these, whose origin could be attributed to the current New Right thinking, are threatening that harmony and unity.

Anne Meade (1991b) speaking to the Barnardo's conference in October 1991 drew on Plato to make a case for the retention of the status quo for in-service training (an integral part of advisory support). We want to re-state her position here:

Plato asked, "Have we any greater evil for a city, than what splits it and makes it many instead of one? Or a greater good than what binds it together and makes it one?"(Plato, as cited in Okin, op. cit. 13).

Okin paraphrased Plato's Republic thus:

Nothing can dissolve the unity of a city more readily than for some of its citizens to be glad and others to grieve over the same thing, so that all do not work or even wish in concert (ibid).

Meade noted that until about 12 years ago, early childhood services in Aotearoa/New Zealand had a reputation for being divided and unable to "work in concert". They were often criticised and entreated to coordinate (e.g., Barney, 1979). Shared in-service courses were a key factor that brought unity into the diversity. It is therefore ironic that early childhood organisations are being persuaded to compete with one another, especially when the focus of the competition is scarce in-service and support resources! The model of tendering for in-service contracts seems designed to set up the situation that Plato abhorred, where some groups "will be glad and others will grieve over the same thing." It seems inevitable that early childhood groups would become constrained to not work in concert, and unity in the early childhood sector would start to dissolve. 
Meade continued:

Plato's solution to this threat was communal ownership. When I asked myself how this could be achieved in the early childhood sector, I concluded that the Early Childhood Developmental Unit is the obvious communal "owner" of in-service and support resources. Therefore, the question has to be asked, "Do we need to change the status quo?" (Meade, 1991b, p. 7)

c) Non-Compulsory Registration of Kindergarten Teachers

The issues in this area are the same as those for the school sector. In essence the concern is that children could have to deal with unqualified teachers with the result that lower quality of work could ensue. This danger may be greater now that associations have begun to secede from the New Zealand Free Kindergarten Union which traditionally was the body responsible for by-laws regarding kindergarten teaching appointments.

d) Change in Ratio for Under-Two Year Olds in Mixed Age-Group Centres A further announcement in the Budget was that the required staff/child ratio for under two-year-olds in mixed-age group centres would be 1:5 instead of the minimum of 1:4 set down in the 1990 Regulations. This change went against all research-based recommendations for quality care and education (e.g., Podmore and Craig, 1991) and is feared as an unsafe figure (May, 1991). The change was also accompanied by the statement that no mandatory staff/child ratio or qualifications guidelines would apply for the purposes of chartering; centres would be "encouraged" to improve on the minimums set down in the 1990 regulations but failure to do so would not result in the withholding of the charter and the concomitant funds. This was a clear blow to the intention that the chartered centre would be one that operated to quality rather than minimum standards.

\section{Parents as First Teachers (PAFT)}

The Budget saw "almost $\$ 1$ million" set aside to begin the development of this new policy (Minister of Education, Press Kit, 30 July, 1991). The history and arguments surrounding the introduction of the PAFT policy onto the Aotearoa/New Zealand early childhood scene have been documented elsewhere (Dalli 1990a). By the end of 1990 early childhood educators were still mystified by the determination of the Minister of Education to persevere with his intention to import this project from the United States. The mystification arose from the fact that (1) the project seemed to offer services that in Aotearoa/New Zealand were already being provided by different early childhood and parenting groups; (2) no consultation about the project had been held with any early childhood people; and (3) it seemed more appropriate that the early childhood sector should concentrate on improving the quality of existing services rather than embark on new programmes that might duplicate existing services. In the face of these objections the Minister of Education portrayed the policy as a new initiative which would be operated with new money (Smith, 1990).

The 1991 Budget press release "Government supports accessible quality Early Childhood Education" suggested that the "almost \$1 million" it would take to set the project running might well derive from savings made from the reduction in funding for under-two year olds attending a chartered service. Earlier that year (e.g., Evening Post, 24 January 1991) it had also been announced that the PAFT project would be trialled in four centres and be administered by the Plunket Society. The Minister of Education was quoted as saying that Plunket nurses already had health training and would only need to be trained in language development. In September 1991 it was announced that the trials would start early in 1992 and be co-ordinated by a national coordinator based in Dunedin. According to the president of the Plunket Society, Pat Seymour, Plunket nurses would act as parent-educators, a role that was similar to the one they already filled; the extra resources that the PAFT policy would make available to the Plunket Society would enable that work to be done at greater depth (Evening Post 25 September, 1991 and Dominion Sunday Times, 29 September, 1991).

These developments have served to bear out the concerns about the PAFT project that existed in the early childhood world in 1990. Mainstream early childhood educationists or early childhood groups 
have still not been consulted on the programme and yet it could be badly-needed and much campaigned-for early childhood money that is being diverted to support the programme. The Plunket Society, like other voluntary organisations such as the IHC, is undergoing a time of obvious retrenchment. At the time of writing the Society had just announced it would be substituting visits by nurses to family houses by group meetings of parents with a Plunket nurse at Plunket clinics. This is clearly a cost-saving exercise. It is surprising that at such a time the Plunket Society has agreed to take on responsibilities that will place additional demands on its already stretched workforce.

\section{Slow Decision-making for Services with Different Cultural \\ Backgrounds}

Before concluding this review, it should be noted that some groups sought change in 1991, and were frustrated by slow decision making. We refer to the Te Kohanga Reo Trust who wanted the New Zealand Qualifications Authority to accredit them and to approve their new training course for Kaiako, and the Ministry of Education to fund this training course. Months of hard work reaped some rewards, but it was not until January 1992 that the course was approved and pilot funding granted.

A'oga Amata, the Samoan language nest, took another route to avoid the painful process experienced by Te Kohanga Reo in 1991. The route they chose in 1991 was to come under the umbrella of Wellington College of Education which now faces the challenge of ensuring the course retains its cultural appropriateness.

\section{Conclusion}

For about a decade, people in the early childhood sector have demonstrated the strength and effectiveness of a field with "the ability to think, vision or act as a whole" needed for excellence (Kagan, 1990, p. 14), in other words the ability to act with integrity. That integrity can embrace diversity - in fact, it must. However, a number of events in 1991 threatened the possibility of achieving excellence in early childhood care and education.
Integrity in the sense of "making whole and linking disparate parts" (ibid, p. 13) was threatened by a) issues related to the bulk funding of kindergarten teachers salaries; and b) the attempt to tender out advisory support and in-service training activities.

Integrity in the sense of having ethical principles was threatened by a) the manner in which the Statement of Desirable Objectives and Practices was introduced in many parts of New Zealand; b) the two attacks on the quality of infant and toddler education by reducing bulk funding to these groups and by allowing a ratio of 1:5 which cannot result in quality experiences; and c) the setting of training points for licences and charters short of the 120 points needed for staff to obtain a valuable portable qualification (the Diploma of Teaching - ECE).

Altogether, 1991 was not a happy year in the history of early childhood care and education in Aotearoa/New Zealand; we can only hope 1992 will be an improvement.

\section{Notes}

1 In some other countries, accreditation of early childhood facilities serves a purpose similar to charters.

2 A calculation by Dr Crispin Gardiner.

\section{References}

Athey, C. Extending Thought in Young Children: A Parent-Teacher Partnership. London, Paul Chapman Publishing Ltd, 1990.

Balaquer, I. and Penn, H. "Quality in Preschool Services", A paper given to a European Community Technical Seminar, May 1990.

Barney, D. Availability of Pre-school Education, in B. O'Rourke \& J. Clough (Eds.) Early Childhood in New Zealand. Auckland, Heinemann Educational Books (NZ) Ltd, 1979.

Bredekamp, S. (Ed.) Developmentally Appropriate Practice in Programs Serving Children from Birth Through Age 8. Washington, DC, NAEYC, 1987.

Bronfenbrenner, U. The Ecology of Human Development. Cambridge, Mass, Harvard University Press, 1979.

Dalli, C. (a) "Policy Scripts for Children's Lives". Paper delivered at the NZARE conference, Auckland College of Education, December 1990. 
Dalli, C. (b) "Early Childhood Education in New Zealand: current issues and policy developments". Early Childhood Development and Care Vol. 64, 1990, pp. $61-70$.

Early Childhood Management Handbook. Wellington, Ministry of Education, 1989. Education Gazette, "Early Childhood Charter Guidelines: A Statement of Desirable Objectives and Practices", A Supplement to the Education Gazette, 14 December 1990.

Farquhar, S. "Quality Early Childhood Education and Care: What do we mean?" Early Childhood Development and Care, Vol. 64, 1990.

Farquhar, S. Experiences of Charter Development in Early Childhood Centres in 1990. Wellington, Ministry of Education, 1991.

Funding Review Team "Early Childhood Care and Education Funding Review. Wellington, GP Print, 1991.

Kagan, S. Excellence in Early Childhood Education: Defining Characteristics and Next-Decade Strategies. Washington, DC, US Dept of Education, 1990

Lange, D. Before Five: Early Childhood Care and Education in New Zealand. Wellington, Department of Education, 1989.

Lauder, H. Tomorrow's Education, Tomorrow's Economy. Report commissioned by the Education Sector Standing Committee of NZ Council of Trade Unions, June 1991.

May, H. "Real danger in broken promises". Education Times, Dominion Sunday Times, August 18, 1991.

McNaughton, S. \& Ka'ai, T. Two Studies of Transitions: Socialisations of Literacy; and Te Hiringa TakeTake: mai i te Kohanga Reo kite Kura, Maori Research and Development Unit, Education Department, University of Auckland, 1990.

Meade, A. Education to be More, Wellington, Department of Education, 1988.

Meade, A. (a) "Boffins in Early Childhood Services", Proceedings of the Fifth Childhood Convention, Dunedin, September 1991.

Meade, A. (b) "Issues in Early Childhood Education in the 1990s", A paper given at the Barnardo's conference, Wellington, 19 October 1991.

Meade, A. and Kennedy, P. "Early Childhood Training and Qualifications Before and Beyond 2000", A paper given at the Qualifications for 21st Century conference, Wellington, 21-24 January 1992

Okin, S. M. "Philosopher Queens and Private Wives: Plato on Women and the Family", in Mary L. Shanley and Carole Pateman (Eds.) Feminist Interpretations and Political Theory. Cambridge, Policy Press/Basil Blackwell. 1991.
Podmore, V. "Infants and Toddlers in NZ Child Care Centres: Priorities for Research and Practice", Australian Journal of Early Childhood, Vol. 15 (4), 1990.

Podmore, V. and Craig, B. Infants and Toddlers in NZ Childcare Centres, Final Report. Wellington, NZCER, 1991.

Smith, A. B. and Swain, D. Childcare in New Zealand, People, Programmes and Policies. Wellington, Allen and Unwin/Port Nicholson Press, 1988.

Smith, Hon L. Education Policy: Investing in People, Our Greatest Asset. Wellington, GP Print Ltd, 1991.

Smith, L. "Parents as first teachers": speech notes, NZCER 2nd Research into Education Policy Conference, August, Wellington, NZCER, 1990.

Varnham, M. "For childcare parents: trial by Charter". Evening Post, 5 June 1991.

Wells, C. "The Impact of Change: Against the Odds", keynote address. Fifth Early Childhood Convention, Dunedin September 1991.

Whitebook, M. et al. Who Cares? Childcare Teachers and the Quality of Care in America. Report of the National Child Care Employer Project. Los Angeles, UCLA, 1989.

\section{The authors}

Anne Meade is a Senior Lecturer in Education at Victoria University. She teaches courses on early childhood care and education at undergraduate and postgraduate levels. In 1988, she convened the Working Group on Early Childhood Care and Education which prepared Education to be More.

Carmen Dalli is a Lecturer in Education at Victoria University. She teaches courses in human development and early childhood education and is currently engaged in doctoral research in ECE. 